\title{
Examination of Restriction of Free Speech under International Covenant on Civil and Political Rights (ICCPR) in Reference to Prevention of Electronic Crimes Act 2016, Pakistan
}

\author{
Sheraz Khan, Pardis Moslemzadeh Tehrani
}

\begin{abstract}
This study aimed to explore the regime for the restriction of freedom of speech under ICCPR. Besides, it assesses the standards and level of freedom of speech restriction under technology law in Pakistan, PECA-2016. A through document analysis of ICCPR and cyber law depicts that at the standards for freedom of speech is far below then the criteria given in an Article 19(3). Furthermore, it appeals to the policy makers and legislators to bring the restriction of freedom of speech in technology law Pakistan at par with that of ICCPR. Nevertheless, it should be amended or repealed to improve the standards for the freedom of speech in the technology law in Pakistan (PECA-2016).
\end{abstract}

Index Terms: Cyber Law; Freedom of Speech; ICCPR; PECA-2016

\section{INTRODUCTION}

It is well established principle that right to freedom of speech is the fundamental and inevitable right of human species. It is the foundation of any democratic society. It provides base and protection to other human rights and multiplies the dignity of human species in democratic societies (Aswad, 2018). But on the other hand it is also acknowledged that right of free expression is not absolute and encountered with certain restrictions and limitations. These restrictions enjoy legal status under article 19 of ICCPR. It becomes the liability of every democratic society to keep balance with regard to governance between the allowed restrictions and observance of freedom of speech (Malik, 2018).

It is important to know those circumstances and the reasons behind those circumstances in which authorities are allowed to block and censor websites and channels in pursuant of international standards and laws. At the beginning it is important to note censoring and blocking of websites events in Pakistan is equal to curtailment of freedom of speech which is not only a global human right but also a constitutional right. This restricting of freedom of speech has attracted growing attention among regional and international human rights organizations (Adnan \& Fatima,

Revised Manuscript Received on September 22, 2019.

Sheraz Khan, Student of Faculty of Law, University of Malaya, 50603, Wilayah Persekutuan, Kualalampur, Malaysia.

Dr.Pardis Moslemzadeh Tehrani, Senior Lecturer of Faculty of Law, University of Malaya, 50603, Wilayah Persekutuan, Kualalampur, Malaysia, pardismoslemzadeh@um.edu.my
2018). It is a live legal issue in Pakistan and among the nations of the globe which needs redressal on priority basis. This chapter is structured as follows: first, the regime for the restriction of freedom of speech under ICCPR be set out; and second, relevant provisions of PECA will be assessed in juxtaposition to principles embodied under ICCPR with regard to restrictions of freedom of speech. Hence, it tends to dig out the reality that whether the restrictions of free speech under PECA is in line with principles and standards embodied in article 19(3) of ICCPR.

\section{A. Regime For The Restrictions Of Freedom of Speech Under ICCPR}

Under international law and regional law, freedom of speech can be restricted under certain circumstances. The guiding torch in this regard is the article 19(3) of ICCPR. According to article 19 of ICCPR:

1. Everyone shall have the right to hold opinions without interference.

2. Everyone shall have the right to freedom of expression; this right shall include freedom to seek, receive and impart information and ideas of all kinds, regardless of frontiers, either orally, in writing or in print, in the form of art, or through any other media of his choice.

3. The exercise of the rights provided for in paragraph 2 of this article carries with it special duties and responsibilities. It may therefore be subject to certain restrictions, but these shall only be such as are provided by law and are necessary:

(a) For respect of the rights or reputations of others;

(b) For the protection of national security or of public

order (order public), or of public health or morals."1

Besides, ffreedom of expression is also protected in UDHR, ECHR, and some other regional documents like African charter on Human and people's rights and American Convention on Human Rights etc. But still it can be said that freedom of expression is relative concept and not absolute. Hence, it can be depicted that at regional and international level and national level several documents permit to restrict the freedom of speech. But subject to the condition that such

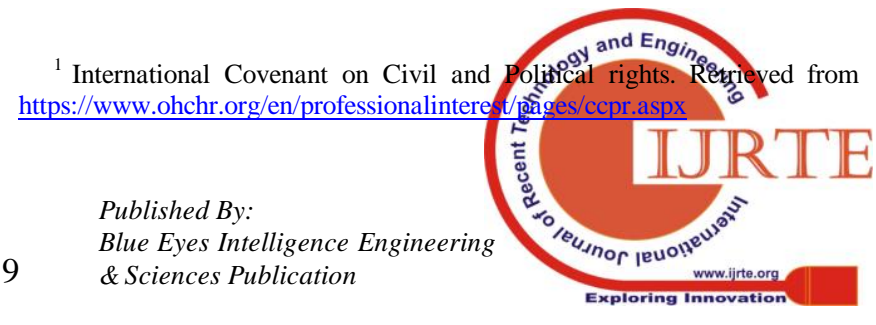


restrictions must follow well defined criteria and rest upon some indicators (Gagliardone, Gal, Alves, \& Martinez, 2015).

\section{1) Legitimate Aim}

Secondly, the interference and restriction must serves a legitimate purpose. Shepherd (2017) explained that there is well defined list which enlists various aims and purposes in international treaties which are deemed to be legitimate and can be treated as plausible grounds for the restriction of freedom of speech. Hence to fulfil this part of test it is of the prime importance that restriction must and shall serve a legitimate cause. However this element of legitimacy cannot be used for political or personal purposes. Foe illustration let's take the example of hate speech when it disrepute's or endangers the respect of other people then it will be termed as legitimate aim.but restricting speech in the name of hate speech which provides criticism of the policies of government does not serve legitimate cause (Muntarbhorn, 2017).

\section{2) Necessity And Proportionality}

Third, there should be a relation of necessity, this implies that the protection and securement of defined aim should be a necessary requirements for the betterment of state and democracy. Further, it means that there should be a dire need for the interfering and restriction of freedom of speech. The state when restrict the free speech it should justify such restrictions by showing the relevancy and sufficiency test in order to secure defined aim. In addition, Carter (2017) identified that such restriction should have direct relation with the purpose for which restrictions are made. In this regard also the European Court of Human Rights has showed great concern regarding the impact of restricting free speech and stressed upon states that when there is no pressing need for restriction, freedom of speech cannot be restricted.

On the other hand side it is the utmost duty of the state to protect their citizens from terrorist attacks and to maintain the law and order situation. And for this purpose the actions of the state must be relevant and under the guidance of law. Nevertheless, it is important that criminal offences should be clearly defined and also there should be a clear illustration about the parameters for which restrictions of freedom of speech can be made. In this regard it is worthy mention the offence of terrorism poses severe threats to the enjoyment of rights and exclusively right to freedom of speech. As the offence of terrorism has been defined very narrowly and clear definitions of terrorism is required in order to avoid confusion. Because this narrow definition is not only fatal fir the freedom of speech but also it does not justify the necessity requirement (Haggard \& You, 2015). Likewise in case of hate speech it is necessary that hate speech should be defined clearly and there should be a defined list which encapsulates acts and omissions fall under hate speech. For the restriction of speech there should be pressing need for it, implies that hate speech when endangers the reputation of other people or adds in the disrespect of other people then such restrictions can be justified. In nut shell it can be argued that the European Court of Human Rights has openly stated that free speech is flexible concept rather than absolute concept.
Hence there are certain exception to the rule of practice of free speech which need clear definitions. Besides, it needs clear interpretations and there should be established and convincing criteria for the restrictions of freedom of speech which will show that necessity requirement for the restrictions of free speech (Schabas, 2015).

\section{B. Assessment Of PECA Provisions With Tripartite Test}

\section{1) Legitimacy And Status Of PECA Provisions}

The prime requirement for the restriction of freedom of speech is that it should be provided by law. This implies that the law which provides for the restriction of free speech should be clear and should not embodies vague words. Besides, according to Carter (2017) no section of the statute should be uncertain. While according to article 3 of PECA, "Whoever with dishonest intention gains authorized access to any information system or data shall be punished with imprisonment for a term which may extend to three months or with fine which may extend to fifty thousand rupees or with both." 2 This section embodies couple of words that carries open ended meaning like word dishonest intention, access to any information system and absence of clear definition of information system etc. Make it one of the confused section of PECA (Kugelman, 2018). Hence defeating the prime essence of third proviso of article 19 of ICCPR. When the law is accessible to everyone it can provide for the restriction of free speech. There are situations in which secret laws are legitimate under some circumstances but even though if such laws are handicapping freedom of speech then it is discouraged and common masses show hatred towards such laws. The prime aim of restriction should be the avoidance of harm by spreading rumours and defamation or creating hatred for some segment of society. As there is an authority of European Courts that citizens should be well aware of the rules and regulations and about their applications (Durham \& Torfs, 2016).

According to Stahl (2016), it is crystal clear in the light of ECtHR decisions and from the documents of international human rights organizations that freedom of speech is not only limited to offline medium, it also extends to online medium, hence freedom of speech is also one of the fundamental right on cyber space. The crux of the one of the Human Rights Council resolution 32/13 of July 2016, expressly stated that right of freedom of speech which people enjoy offline is also be enjoyed online. It is the prime responsibility of the state to protect freedom of speech on online medium (Hammer, 2018). Now let' s consider the case of Pakistan where PECA is the guiding legislation for the activities of cyber space accompanied with huge criticism from human rights organizations and civil societies with regard to freedom of speech on cyber space. In addition, section 3 of PECA blatantly put restrictions on online speech which is against the spirit of international principles of human rights. Likewise,

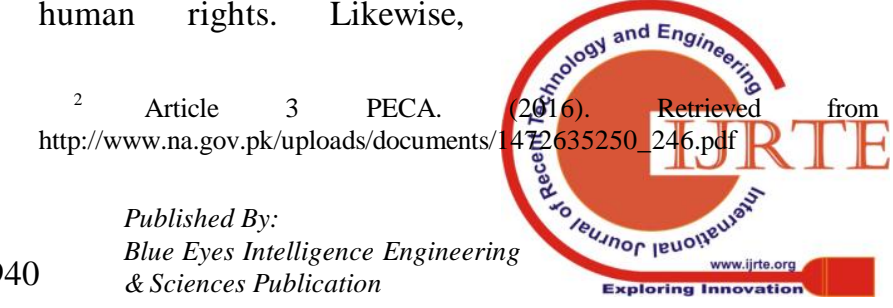


section 4 of PECA embodies as " Whoever with dishonest intention and without authorization copies or otherwise transmit or causes to be transmitted any data shall be punished with imprisonment for a term which may extend to six months, or with fine which may extend to one hundred thousand rupees or with both". According to special rapporteur of $\mathrm{UN}$, this section is also handicapping the online freedom of speech and thus contradicting the legitimacy of restriction of free speech. 3

In many countries of globe the cyber statute empowers the administration with limitless power and give discretionary power to them for the restriction of freedom of speech. For instance, in many states the authorities controlling the broadcast regulation enjoy unchecked power and on daily basis these authorities censor the online speech which is paramount to handicapping free speech. Not it only violates the professional ethics but also it is deemed an attack on the privacy of other people and user of online space. As far as the PECA-2016 is concerned, article 37 give unchecked powers to the authorities of Pakistan state to restrict and interfere with freedom of speech on cyber space (Kelso, 2016). The epitome of article 37 states that it is the discretion of authority to remove or block any information which is not only fatal for the restriction of freedom of speech but also against the norms and standards of ICCPR, to which Pakistan is a part. In addition this article give discretionary power to authorities of Pakistan that without any defined criteria, it is the authorities who will decide to remove or block any information which they consider that such information's are fatal for the security of state or against the Islam, or against the public order and decency and integrity of other human beings. Besides this, it stress upon that authority will prepare SOP' $s$ with consultation of federal government for the transparency, safeguards and effective oversight for the exercise of power but all in vain.

To put it simple, this section give unbridled power to regulating authorities. Hence those administrative authorities enjoy arbitrary power while dealing with restriction of freedom of speech. Hence absence of clear meaning of section and adding power into the hands of authority make it far below the standards for the restriction of freedom under article 19(3) of ICCPR. 4 There is also a view that those laws and regulations which empowers the authorities for restricting freedom of speech should be well defined and limitless and discretionary power should not be given to them in order to avoid misuse. As in the case of Ontario Film Film and Video Appreciation Society v. Ontario Board of Censors, the court considered and discouraged the law granting unchecked powers to authorities for censorship. Court termed that vague and ambiguous law adds to discretionary power which then the authority's misuse for personal gains. The court not only

\footnotetext{
${ }^{3}$ Kaye, D. (2016). Statement of the UN Special Rapporteur on the promotion and protection of the right to freedom of opinion and expression. Retrieved from https://www.ohchr.org/en/NewsEvents/Pages/DisplayNews.aspx?NewsID=16 879\&LangID $=\mathrm{E}$

${ }^{4}$ Aziz, F. (2018). Pakistan's cybercrime law: Boon or bane? Retrieved from https://www.boell.de/en/2018/02/07/pakistans-cybercrime-law-boon-or-bane
}

strike down the law but stressed that in future such laws should not be enacted. Further the court established that law deemed to be clear when it is understand by common citizen, free from vague terms, it should be ascertainable. The restriction of freedom of speech cannot given to authorities without any oversight, otherwise it cannot be termed as law (Hogg \& Bushell, 2017). In addition, it is section 37 of PECA 2016 having same nature which provides unbridled power to authorities, hence defeating the true essence of any law and enactment of such statutes is not only the violation of Pakistan's constitution but also against the standards and norms of ICCPR. .

Likewise when it comes to grant the licenses to broadcasting corporations, again there is unchecked power in the hand of administrative authorities which is also highlighted by UN Human rights committee. The Committee also expresses its concern about the powers and functions of National Communications Agency which also enjoys discretionary power in granting licenses and mostly deny to grant licenses as it is their discretion to grant or not. However, it is well established that restriction for freedom of speech must be provided by law. It is one of the utmost criteria that law must provide appropriate notice in advance to those bodies for which the restrictions for free speech will take place. Otherwise, Hammer (2018) revealed that these laws will have an adverse impact on freedom of expression. As it is stated by the European Court that when a norm does not clearly address to the citizens about the regulation of conduct then such norms cannot be termed as law or regulation. Hence law should be able and capable of appropriate advice to predict the circumstances under which restriction for freedom of speech is allowed or not. While keeping the above scenario, it is the common practice of regulating authorities in Pakistan to seize and seizure without any notice and informing the owner of information system (Hanif, 2016). Furthermore, vague and confused sections of the law are open to wide interpretations by common people and the authorities governing them through such laws. As a result such ambiguous and confused laws are tools of exploitation in the hands of authorities. Hence the relevant authorities do not use such laws for the purpose for which such law are enacted but they use it for personal and political grudges. Courts in several decisions of different jurisdictions has expressly emphasized upon the fact the vague provisions have direct impact on the freedom of speech. In this regard the US Supreme Court has openly expressed that statutes must be enacted clearly and every provision of the statute must be understand by common citizens and in no case such laws should violate the freedom of speech (Matsuda, 2018). But On the flip side of the coin it is also fact that most laws are vague and it is very difficult for a law to be free from vague and ambiguous terminologies.

${ }^{5}$ Kaye, D. (2016). Statement of the UN Special Rapporteur on the promotion and protection of the right to freedom of opinion and expression. Retrieved https://www.ohchr.org/en/NewsEvents/Pages/DisplayNews.aspx?NewsID=16 879\&LangID $=\mathrm{E}$ 
Nevertheless, laws need sufficient flexibility while applying in different circumstances, as well as for keeping relevancy with the passage of time. This fact has also been admitted and recognized by the European Court that certain laws should not be absolute but for the regulations of such laws there should an oversight which may be judicial or executive. Hence it can be said that certainty is the real essence of any law and it is also very imperative for a law that it should keep its pace with the exigencies of time. In nut shell it is fact of the hour that many laws in various jurisdictions have vague terms and poses several critical questions but it is necessary for the state to ensure that such laws should not be misused for the restrictions of freedom of speech (Enarsson \& Lindgren, 2019).

2) Legitimate Aim And Status Of PECA Provisions:

The second parameter of tripartite test focus on the protection of interest which is legitimate and is of imperative nature for the wellbeing of society. There is a list of legitimate interests encapsulated under article 19(3) of ICCPR. To evaluate if legitimate aim is served by restriction of free speech both the cause and effect of restricting free speech should be taken into account. According to Supreme Court of Canada for legitimate aim to be valid is to ensure that what causes restriction has bad impact on the order of society. Beside this criteria there is no other grounds for which restriction of freedom of speech is allowed. And if any legislation provides for it such enactment is against the international of human rights (Newman, 2018). Also according to Indian supreme to serve the legitimate aim should be the sole purpose of law which provides for the restriction of free speech. However those purposes which are not mentioned in constitution and other international laws are not valid grounds for the restrictions of freedom of free speech. Such grounds are deemed ultra vires and against the spirit of law. In this regard some courts cross the limits and focus on specific aims other than legitimate aims which is also detrimental for the practice of freedom of speech (Liang, 2016). As UN special rapporteur to Pakistan has termed that censorship nature of PECA provisions does not serve its purpose. Dad (2018) revealed that the main aim of PECA provisions to create fear among internet users and to put a stop to their online freedom of speech as PECA provisions carry huge penalties. Nine Pakistani citizens have filed a constitutional petition in Pakistan's Sindh High Court in response to recent harassment and arrests of journalists and activists under PECA. The petitioners, who are journalists and activists, that promotes digital freedom and gender rights through advocacy and research,. THE petitioners approached court and argued that under PECA the government has acted unlawfully and its actions are creating an environment of fear, in turn causing a chilling effect on speech RATHER to achieve its objective of national security. ${ }^{6}$ Hence it depicts that relevant provisions of PECA has drastically failed to secure the second test of three part test for restricting freedom of speech. Nevertheless such

${ }^{6}$ MARY MEISENZAHL, M. (2017, August 10). Petition challenges Pakistan's censorship in court. Retrieved from https://www.indexoncensorship.org/2017/06/petition-pakistan-censorship/ restrictions are very dangerous in the interest of democracy and to ensure that rule of law is upheld." (Dad, 2018).

Also the analysis of international courts show that restriction of freedom speech is justifiable only in the case if it serves the legitimate cause. While the stance of European court is quite different and focus on the needs and importance of aim for which restriction is allowed rather than element of legitimacy (Hammer, 2018). However the stance of European court has a devastating effect as it leaves the concept of restricting free speech open and everyone can misuse it according to their own wish. As the concept of legitimacy and proximate necessity is different from state to state. In addition if we analyse the grounds for restriction under article 19(3) is quite general in nature. For instance, rights of others people, national security and public morals are quite open to define and interpretation. However it is necessary to highlight and eliminate those grounds which does not warrant for the freedom of speech but only focus on restricting the freedom of speech (Cassidy, 2015).

Likewise the naughtiest concept which is used for exploitation of restriction of freedom of speech is that of the grounds for national security. This concept is not only misused but used by the political opponents for one another for political grudges. But on the hand it is also fact that national security is above all human rights as corpus of state is prime and others interest are secondary. However, Chen (2017) highlighted there should be clear explanation under national and international for the parameters of national security. As this problem is very common on daily basis as even the judges are confused that which acts or omissions included in the infringement of national security. Also this concept has no oversight mechanism as there is body who determines that what acts or omissions contribute towards the threat of national security. Another issue with this problem is that this concept is closely linked with element of secrecy (Chen, 2017). The case is also not different in terms of Pakistan as in section 11 of PECA, "Whoever prepares or disseminates information, through any information system or device. That advances or is Likely to advance interfaith, sectarian or racial hatred. shall be punished with imprisonment for a term which may extend to seven years or with fine or with both. ${ }^{7}$ The analysis of this sections contemplates that whether advocating the dynamics or fundamentals of a sect or group on social media or TV channels qualify for hatred and whether the aim implied in section is legitimate. So without an iota of doubt this section embodies a legitimate aim which does not qualify the standards for restriction of freedom of speech (Dad, 2018).

Another clear rule with restriction of freedom of speech interns of national security is national security is legitimate of and only if the country protection is the soul and main purpose. Here the rule cause and effect comes true as the cause is big and the effect is devastating. Hence whether it is internal threat or external if it endangers the security of state

\section{then in such case restricting \\ 7 Article 11 PECA.} http://www.na.gov.pk/uploads/documents/1 
freedom of speech is valid and can be justified under international law. ${ }^{8}$ Likewise there is another case where the citizen of Swedish was dismissed on the basis of national security but when he wanted to know about the information, he was not allowed to provide. Hence such sort of activities are not justified from restricting the freedom of speech as restriction of speech is allowed only when it is provided by law. In another decision the Swedish court held that Swedish national security is above all other concerns whether it fair trial or basic human rights (Mendel, 2016). Nevertheless, section 37 and 11 of PECA are the section falling in the aforementioned explanations. These sections not only used for misleading the courts but also do not serve the legitimate cause. $^{9}$

\section{3) PECA Provisions And Status Of Necessity And Proportionality:}

Thirdly, it is primordial that the link between restriction of free speech and legitimate cause should be very necessary. This implies that there is no other alternative to protect the desired interest except restricting free speech. This part refers to the concept which is the basis of loads of international cases (Shepherd, 2017). Unfortunately this is the toughest part of the test to prove. It is more debatable and open to discussion. As it needs strong and reasonable grounds to protect. If such link is developed and justified by state then restriction of freedom of speech cannot be challenged on any forum. The parameter of necessity is imperative notion but complex concept. As it is included couple of items. In this regard the international courts evaluates and assess if there is dire need for restricting free speech or not (Shepherd, 2017). Also this concept is closely linked with the question that whether restriction pursue a legitimate cause or not. Second, it should be the criteria that there should be a rationale and strong reason connected with the aim of interest which is protected (Muntarbhorn, 2017). However, in terms of Pakistan PECA has pressed certain activities with regard to free speech on internet like accessing information system without authorized permission and giving arbitrary powers to authority but despite of that cybercrimes are increasing. This implies that there is a gap between the legitimate aim and necessary cause. Hence it is clear crystal that if other alternatives are present to protect the interest or legitimate cause then in such case restriction of freedom of speech cannot be justified (Sandholtz, 2016). Likewise, according to Supreme Court of Canada, an example of this can be systems to regulate the harmful content in the broadcasting. In few of the countries, in primary legislation there founds a prohibition on directly applicable content. And in some countries, the law makers for work regulations with stakeholders, also the broadcasters, for developing a code of conduct which applies by a system of complaints leading mostly to breach

\footnotetext{
${ }^{8}$ Article 19. (1996). Johannesburg Principles: National Security, Freedom of Expression and Access to Information,[PDF file] Retrieved from https://www.article19.org/wp-content/uploads/2018/02/joburg-principles.pdf

${ }^{9}$ MARY MEISENZAHL, M. (2017, August 10). Petition challenges Pakistan's censorship in court. Retrieved from https://www.indexoncensorship.org/2017/06/petition-pakistan-censorship/
}

warnings. As much as the latter is quite effective and less intrusive until yet and is directed through the essential part of the test. There founds no other reason for why it shouldn't be extended to self-regulatory systems for media. So, if there is the availability of the effective self-regulatory system then it would be quite challenging to justify the layering a statutory system (Sandholtz, 2016).

According to Mendel (2016), a different but closely related notion is that, there should not be an overly broad restriction which can targets not only the legitimate speech but also the harmful speech. Again, it become obvious that if it is not appropriate to go further than is necessary which limit the protected statements. The Inter-American Court has pointed out that: "Implicit in this standard, moreover, is the notion that the restriction, even if justified by compelling governmental interests, must be so framed as not to limit the right protected by national and international law more than is necessary." The US Supreme Court has taken the notice against the hazards and risks of overly broad restrictions on speech and also has warned against it that although the Government aimed to be substantial and legitimate, that aim cannot be followed by means which suffocate basic personal liberties at times the end can be achieved more narrowly (Mendel, 2016). Where in regard to PECA it is perceived that by using the name of hate speech, fundamental/basic rights have been snatched and also doing so by offering an unbridled power to the regulators and the authority. The rational connection, and to a lower level of over breadth, one of the aspects of the necessity test, is related to the practical limitations in PECA (Mohammed, 2016). In order to protect the private as well as the public right, the governments may not always be expected to discover every possible solution to minimize the freedom of expression, though they should not ignore the obvious options and the government of Pakistan has done it which depicts that restricting freedom of speech does not qualify the third part of tripartite test as well. Likewise, even the restrictions that are designed so carefully may be applied occasionally in such a manner which may oversteps the suitable bounds (Mohammed, 2016).

The European Court of Human Rights partly addressed this issue on the basis of application of the doctrine of the "margin of appreciation". So, in Ahmed and others v. United Kingdom, the European Court who are evaluating new regulations that are restricting the official's political activities, indicated that the introduction of the Regulations should have been considered a proportionate response to a real need and should have been identified appropriately and addressed according to the respondent margin of the State of appreciation in this sector. It may be quite reasonable but not much logical precision (Mendel, 2016). Likewise, Dad (2018) depicted that PECA 2016 has not succeeded in developing clear principles related to the application of the 3 part test to restrict the freedom of speech and is also perceived that PECA provisions fervently violates the true spirit of ICCRP's article 19(3).

Finally, it is obvious that restrictions must meet a kind of proportionality test, as well 
as the benefits regarding to protecting the interest should be larger than the harmful effects of freedom of expression. Else, the restriction would never be justified as being in the whole public interest. It not only goes to the substance of a restriction but also to each sanction which is imposed for breach of it which is not reflected in terms of PECA provisions (Dad, 2018). Worldwide, courts are required to address this by requiring a close nexus in between the disputed speech and the risk of harm. Therefore, the Supreme Court of India noticed that the expected danger must not be conjectural, remote or far-fetched. It is necessary to have proximate direct and nexus along with the expression. The expression may intrinsically be dangerous....or it can be said that the expression must inseparably be locked up with the expected action like the equivalent of a 'spark in a powder keg' (Mendel, 2016).

\section{Epitome Of Findings And Analysis}

It speculates that some of provisions of PECA have over broad definitions like section 11 which embodies about hate speech where hate is open to interpretation and can be misused by authority for political or personal grudges.Besides, the word hate does not qualify the standards for the legitimate aim (Dahr, 2016). Likewise section 37 provides for removal of online content where the "the power to block or remove or issue direction, needs some well-defined and established criteria. Hence the very definition is in clear contradiction with first proviso of article 19(3) and defeats the standards for restriction of freedom of speech (Dad, 2017). Mendel (2016) depicted that the Inter-American Court of Human Rights issued an Advisory Opinion regarding restricting freedom of speech in which it assessed the meaning of the term 'law' which states that the restrictions may be placed on the enjoyment by exercising the rights or freedoms recognized herein may not be practiced/applied other than in accordance with laws passed for reasons of common interest as well as in accordance with the aim for which these restrictions were developed. While in PECA the ambit of section 37 is so broad and vague that authority can apply it to general restrictions not mentioned in section 37 text. This is not only in the contradiction of first proviso of article 19(3) of ICCPR but also defeats the essence of second proviso which embodies about the legitimate aim. Nor the general restriction outside corpus of section qualify for the necessity and proportionality test. ${ }^{10}$

In 2011, in the General Comment 34 about Article 19 of the ICCPR, the UN Human Rights Committee stated that "generic bans on the operation of certain sites and systems are not compatible" with Article 19 of the ICCPR19. The government of Pakistan has banned the article 19 and other online websites which clearly contradicts the three part test and appeals for the improvement of PECA (Liaquat,

\footnotetext{
${ }^{10}$ O Brien, D. (2016, August 18). The Global Ambitions of Pakistan's New Cyber-Crime Act: Legislative analysis. Electronic frontier foundation [blog post] Retrieved https://www.eff.org/deeplinks/2016/08/global-ambitions-pakistans-new-cyber -crime-act?page $=4$
}

Qaisrani, \& Khokhar, 2016). Similarly section 3 and 4 embodies the word dishonest and information system which has no clear meaning, nor does the PECA provide defined ambit for the terminologies which in clear contradiction with first proviso of article 19(3). The clear direction of UN is that States should give margin to the internet regulators and intermediaries rather to compel them for openly blockage or removing of contents from online medium. However states can give such orders when such orders are in line with standards and norms according to international human rights law. It is also imperative that states should preclude to put pressure on internet regulators for restricting the freedom of speech (Dad, 2017). It is also imperative that states should preclude to put pressure on internet regulators for restricting the freedom of speech. while this practice is everyday game of the town in Pakistan. Furthermore, Pakistan adopt, or revise, laws and policies which provide cruel restriction on encryption and anonymity, which is not only unnecessary but inherently disproportionate. Hence it does not qualify as a legitimate reason for the restriction of freedom of speech (Baloch, 2016). The mechanism for human rights has exclusively stressed upon the need to reform the procedure for blocking of websites. According to 2011 Joint Declaration about Freedom of Expression regarding the Internet, it was termed that blocking of internet websites and removal of online content without any justifications, is a cruel and unjustified act. This act is paramount to handicapping the freedom of speech like the one when a newspaper or print media is brought under extreme censorship. Restriction of free speech can only be justified according to the norms and standards of international standards, for instance like to prevent children from sexual abuse (Mendel, 2016).

\section{CONCLUSION}

In conclusion, it can be said that the comprehensive regime for the restriction of freedom of speech is embodied in article 19 of ICCPR. The standards are mentioned in the form of three part test system which depicts that restrictions should be provided by law. This implies that law advocating for the restrictions of freedom of speech should be clear and free from dubious terminologies while analysing the relevant provisions of PECA, it come to the fact several terms of section are dubious an hence defeating the essence of first proviso of article 19(3) of ICCPR. Likewise the However special representative regarding freedom of media termed that unless there is no pressing needs for restricting freedom of speech, blocking of websites, removal of online content is a serious threat towards the freedom of speech. These can only be restricted under certain well defined circumstances which is also absent in case of provisions of PECA.

This paper highlights that restricting freedom of speech should pass from the strictest test. Every statute should encapsulate necessary safeguards for the practice of freedom of speech. When a website is blocked it should be justified on rationale basis. Nevertheless, when it is 
allowed to block the websites then it must have a strong basis provided by law, ordered by court, there should be a necessary link between the restrictions and to serve the legitimate cause. However it is very imperative when a court or authority is giving order for restricting freedom of speech then such authority or court must take into account the impact of order on lawful content. Also the indication should be made that what sort of technology can be used for blocking purposes. In addition all those who are affected by such order should provide ample opportunity to hear and to address their grievances But unfortunate all such measures are like dreaming in terms of PECA-2016. Nevertheless, all those practices which discourage the freedom of speech and without any justifications restrict freedom of speech should be criticised.

\section{REFERENCES}

[1] Adnan, M., \& Fatima, B. (2018). Political, Economic and Social Governance in Pakistan: Its Practices and Issues. Journal of the Research Society of Pakistan, 55(1).

[2] Aswad, E. (2018). The Future of Freedom of Expression Online. Duke Law \& Technology Review, Forthcoming.

[3] Baloch, H. (2016). Internet Rights and Legislation in Pakistan: A Critique on Cyber Crime Bill, 2016. Accessed on 23rd June.

[4] Carter, E. L. (2017). "Not to Disclose Information Sources": Journalistic Privilege Under Article 19 of ICCPR. Communication Law and Policy, 22(4), 399-426.

[5] Cassidy, E. K. (2015). Restricting Rights? The Public Order and Public Morality Limitations on Free Speech and Religious Liberty in UN Human Rights Institutions. The Review of Faith \& International Affairs, 13(1), 5-12.

[6] Chen, A. K. (2017). Free Speech and the Confluence of National Security and Internet Exceptionalism. Fordham L. Rev., 86, 379.

[7] Conte, A., \& Burchill, R. (2016). Defining civil and political rights: The jurisprudence of the United Nations Human Rights Committee: Routledge.

[8] Cram, I. (2016). Contested words: legal restrictions on freedom of speech in liberal democracies: Routledge.

[9] Dahr, J. M. (2016). An investigation of requirements traceability practices in software companies in Malaysia. Universiti Utara Malaysia.

[10] Dembour, M.-B. (2015). When humans become migrants: study of the European Court of Human Rights with an Inter-American counterpoint: Oxford University Press, USA.

[11] Durham, W. C., \& Torfs, R. (2016). International Human Rights Law and the Islamic Headscarf: A Short Note on the Positions of the European Court of Human Rights and the Human Rights Committee Islam, Europe and Emerging Legal Issues (pp. 101-104): Routledge.

[12] Enarsson, T., \& Lindgren, S. (2019). Free speech or hate speech? A legal analysis of the discourse about Roma on Twitter. Information \& Communications Technology Law, 28(1), 1-18.

[13] Gagliardone, I., Gal, D., Alves, T., \& Martinez, G. (2015). Countering online hate speech: Unesco Publishing.

[14] Haggard, S., \& You, J.-s. (2015). Freedom of expression in South Korea. Journal of Contemporary Asia, 45(1), 167-179.

[15] Hammer, L. M. (2018). The International Human Right to Freedom of Conscience: Some Suggestions for Its Development and Application: Some Suggestions for Its Development and Application: Routledge.

[16] Hogg, P. W., \& Bushell, A. A. (2017). The Charter Dialogue Between Courts and Legislatures C:(Or Perhaps The Charter Of Rights Isn't Such A Bad Thing After All) Bills of Rights (pp. 187-236): Routledge.

[17] Kelso, R. R. (2016). The Structure of Modern Free Speech Doctrine: Strict Scrutiny, Intermediate Review, and Reasonableness Balancing. Elon L. Rev., 8, 291.

[18] Koenig, M., Bolden, J., \& Kymlicka, W. (2015). Governance of religious diversity at the European Court of Human Rights. International approaches to governing ethnic diversity, 51.

[19] Kugelman, M. (2018). Pakistan in 2017: A Year of Domestic Turmoil. Asian Survey, 58(1), 100-109.

[20] Liang, L. (2016). Free Speech and Expression The Oxford Handbook of the Indian Constitution.

[21] Liaquat, S., Qaisrani, A., \& Khokhar, E. N. (2016). Freedom of Expression in Pakistan: A myth or a reality.
[22] Malik, A. U. (2018). Governing Abuse of Free Speech during Elections in Pakistan. South Asian Studies, 33(1), 239-251.

[23] Matsuda, M. J. (2018). Public response to racist speech: Considering the victim's story Words that wound (pp. 17-51): Routledge.

[24] Mendel, T. (2016). The Fiftieth Anniversary of the Freedom of Information Act: How it Measures up Against International Standards and Other Laws. Communication Law and Policy, 21(4), 465-491.

[25] Mohammed, F. (2016). PECA 2015: A Critical Analysis of Pakistan's Proposed Cybercrime Bill. UCLA J. Islamic \& Near EL, 15, 71.

[26] Muntarbhorn, V. (2017). The International Covenant on Civil and Political Rights (ICCPR) and Thailand The Core Human Rights Treaties and Thailand (pp. 141-194): Brill Nijhoff.

[27] Newman, D. G. (2018). Interpreting Freedom of Thought in the Canadian Charter of Rights and Freedoms. Forthcoming in (2019), 85.

[28] Raz, J. (2017). The rule of law and its virtue The Rule of Law and the Separation of Powers (pp. 77-94): Routledge.

[29] Sandholtz, W. (2016). Expanding Rights: Norm Innovation in the European and Inter--American Courts.

[30] Schabas, W. A. (2015). The European convention on human rights: a commentary: Oxford University Press.

[31] Shepherd, A. (2017). Extremism, Free Speech and the Rule of Law: Evaluating the Compliance of Legislation Restricting Extremist Expressions within Article 19 ICCPR. Utrecht J. Int'l \& Eur. L., 33, 62.

[32] Smit, D. (2015). Cyberbullying in South African and American schools: A legal comparative study. South African Journal of Education, 35(2), 1076.

[33] Stahl, T. (2016). Indiscriminate mass surveillance and the public sphere. Ethics and Information Technology, 18(1), 33-39.

\section{AUTHORS PROFILE}

Sheraz Khan, is Student of Faculty of Law, University of Malaya, and my area of interest is law. 50603, Wilayah Persekutuan, Kualalampur, Malaysia.

My name is Dr.Pardis Moslemzadeh Tehrani, and I am Senior Lecturer of Faculty of Law, University of Malaya. My area of interest is Law and postal address is 50603, Wilayah Persekutuan, Kualalampur, Malaysia, pardismoslemzadeh@um.edu.my 